\title{
STRENGTHENING THE DEVELOPMENT PARTNERSHIP BETWEEN THE EU AND SOUTH ASIA: A CONTEMPORARY ANALYSIS
}

\author{
Simant Shankar Bharti ${ }^{1}$
}

\begin{abstract}
The relations between European Union (EU) and South Asia are not new. However, South Asia is one of the fastest growing economies of the world; the EU's development policy has given less attention to this region. This paper aims to elucidate and evaluate the EU engagement towards South Asia through development policy and generate an argument on reasons for the EU to strengthen its strategy in the region. Pursuing its comprehensive attention towards the region, the EU intends to address different development- related challenges under its 'Agenda for Change' initiation. The main question addressed in this research is 'Why South Asia is important for the EU?' The discussion below attempts to incorporate empirical analysis regarding challenges and prospects for the EU in the region. In terms of theoretical approach, this paper follows a neoliberal perspective to analyse the EU development policy. The main findings of the research is that however the EU has strengthened its development partnership with South Asia, the EU is still not considered as a main actor in the region.
\end{abstract}

KEY WORDS: European Union, South Asia, SAARC, Development Policy, Sustainable Development.

\section{INTRODUCTION}

The European Union (EU) is interested in strengthening its development partnership and connectivity towards the fastest-growing region of Asia, i.e., in continuous focus on the South Asian Association for Regional Co-Operation (SAARC) and South Asian countries. The EU has ensured that its cooperation partnership and connectivity in the context of hard and soft infrastructure will advance systematically. The EU has already made its development commitment to the developing countries politically and strategically concerned with South Asia and fall under the category of Asian and Latin American (ALA) countries. Nevertheless, ALA regulation was replaced with the Instrument for Development (DCI), which is incorporated with regional

\footnotetext{
${ }^{1}$ Faculty of Political Science and International Studies, University of Warsaw, Krakowskie Przedmieście 26/28, 00-927 Warszawa, Poland, e-mail: s.bharti@student.uw.edu.pl, ORCID: 0000-0002-9578-7066.
} 
programming for Asia in 2007. The DCI is an instrument that finances the Multiannual Indicative Programme (MIP) 2007-13. Currently, under MIP for Asia 2014-2020, South Asia is defined as a sub-region. 22\% population of the world occupies almost 4\% of the land of South Asia (Tripathi, 2011, p. xi). The Indian subcontinent is of great geostrategic importance to the EU that is forging ties with countries in South Asia as a strong economic player and major development stakeholder. Under its development policy, the EU is focussing on aid donors and working to foster the institution building, democracy, good governance, agriculture, development, and human rights. The EU is also concerned about the security in that region preferably in the case of Kashmir disputes and Afghanistan.

The subject of the paper covers the development cooperation policy between the EU and South Asia. It emphasises contemporary discourse among scholars about the EU's increasing interest in the region. However, this region was neglected until 1990 and the area was of less EU concern, because the EU was more engaged within African, Caribbean and Pacific States (ACP). (Jain, 2015, p. xv; Tripathi, 2011, p. 194; Birochhi, 1999). Hence, it was limited in providing more economic assistance. Nevertheless, the EU has adopted the "Agenda for Change" incorporated with the 2030 UN Sustainable Development Goals (SDGs). Then, it has launched the Regional Programme for Asia Multiannual Indicative Programme (MIP) 2014-2020, which is covering the whole of South Asia. Now, relations are improved in joint strengthening to achieve development goals in order to promote trade and economic cooperation. The EU's development policy is incorporated to a neoliberal agenda as Free Trade Agreements (FTAs) with its partner countries, where development assistance comprises a tool for FTA negotiations with developing countries.

Furthermore, the EU is interested in encouraging regional integration through support to the SAARC, which is almost dysfunctional. The EU wants to play a crucial role in the region by having observer status with the SAARC. Although, this discussion aims to focus on development cooperation such as the "MIP 2007-13" and mainly "MIP 2014-2020. However, the aim of the paper is covered by following objectives:

1) Understanding the importance of South Asia for the EU;

2) Examining the role of South Asia in the EU's development policy;

3) Delineating the EU's commitment to development cooperation in the context of contemporary challenges. 
The EU is concerned about a strong development partnership with South Asia. Therefore, its neoliberal strategy incorporates development such as financial and technical aid as well as economic cooperation, which includes regional peace and stability, poverty alleviation, human rights, agriculture development, sustainable development, good governance, civil aviation, and labour rights.

However, there are three important questions to understand the deeper development partnership between EU and South Asia such as

1) How is South Asia figured in the EU's development policy?

2) Why is South Asia an important region for the EU? And

3) What are the prospects and challenges to the EU and South Asia partnerships?

The structure of the paper is divided into four substantial discussions. Firstly, background of the general EU development policy towards South Asia is discussed. Based on the EU's increasing engagement in the region the second section deals with strategic importance of the region for the EU's development policy. Likewise, the third section focuses on the challenges associated with the EU approach towards the region. Paper argues that considering the increased activities of other stakeholders in the region has been undermined the EU's policy here. In addition, based on this discussion, conclusions and the policy recommendation are to be provided.

\section{THEORETICAL AND METHODOLOGICAL APPROACH}

Christoph Hermann argued in his work "Neoliberalism in the European Union" that the EU has neoliberal agenda as 'free trade and capital mobility' and 'restructuring of the welfare states'. The budgetary restraint brought a cruel consequence of human security especially in the third world, where a large amount of population in various countries is experiencing extreme poverty. Therefore, neoliberal policies not only talk about the privatisation of public enterprises but also talk about pension and good governance (Hermann, 2007, p. 62). It emphasises more on the broader implementation of the neoliberal agenda through the development and trade policy not only with European countries but also with developing countries. However, FTA has become one of the important bargaining and negotiation instruments to achieve its interest through development policy. The EU has used its neoliberal agenda to influence the regional integration through supporting SAARC, which is now a dysfunctional entity. The EU 
wants to play a crucial role to have observer status with the SAARC in the region. The EU is concerned about a strong development partnership with South Asia in the context of financial and technical aid as per economic cooperation. However, its neoliberal agenda incorporated regional stability, poverty alleviation, human rights, agriculture development, sustainable development, good governance, civil aviation, and labour rights as an instrument towards South Asia.

Primarily, the paper uses content analysis as the main methodological approach. Analysing the primary and secondary sources available related to the EU development policy toward South Asia, the research adopts qualitative methods that allow us to form an argument and do a substantial discussion in order to draw a conclusion. The qualitative content analysis helps with particulars of latent interpretation and quantitative content analysis supports manifest meaning from analysis of the latest data as well as debate in the literature. It also focuses on "what" and "why" questions in order to address an interpretation for several possibilities (Pashakhanlou, 2017, p. 449). This applies in very broad range of the South Asian cases by comprehensive case- inquiry from both variables. For this research, the first variables comprise the EU geostrategic presence in the region, and second is the EU development cooperation policy. Basic understanding of both the variables is that they are complementary to each other, where the EU's geostrategic presence is completely dependent on the development cooperation policy. This brings an understanding of the complex issues of South Asia. A deductive approach makes a broad generalisation of specific observations. These all have been used to investigate a research problem through a deductive approach for a broad contextual generalisation of the EU and South Asia relationship. The 'neoliberal approach' as the theoretical framework was used in this study for driving the role of the EU in South Asia. For the growing economy, this approach is helping to negotiate with them to share values and norms.

In the current scenario, the EU is facing problematic challenges such as BREXIT, the COVID-19 effect, the migration problem, and economic pressure. The EU has engaged itself in a sustainable development agenda for developing countries, which is intervening as a powerful independent regional power as well as an international donor. The recent ongoing debate over the issues is aimed at seeking attention over the EU future as a supranational body that is raising a big assumption as a development leader.

The development policy is an important part of its external action programme, which is engaging MSs in the neoliberal normative perspectives 
of democracy and human rights promotion around the world. The EU has the same agenda towards South Asia for strengthening partnerships to improve socio-economic development. After a long ignorance of this region, the EU is facing a big challenge to improve this relationship and change its image in the arena of international relations.

\section{REVIEW OF LITERATURE}

Tripathi (2011) claims in his book "Developmental Role of the European Union in South Asia" that international development assistance is a significant part of international relations, which provides diplomatic tools to developing countries in the terms of their foreign policy. South Asia is currently an important region for the EU and the 2005 Strategy Paper pays more importance here. The EU has engaged South Asia with several developmental activities and is playing a more prominent role with involvement in political, economic, and social stagnation of development policy. It is more concerned about security where $9 / 11$ raised a serious question on South Asia, which was also considered a home of terrorism, especially Afghanistan and Pakistan. Initially, the region was kept ignored for decades until the 1990s due to several reasons such as the transformation stage and internal issues of the Union and close ties with the African, Pacific, and Caribbean (ACP) countries. After adopting an open market policy of globalisation, the countries of South Asia have emerged as the fastestgrowing economies. This was the time when the EU expressed the goal for active participation through its development policy in the region. Therefore, the EU is watching South Asia very closely, and in the future, it could go for further strategic, geopolitical, and economic partnerships with every country in the region. The EU is in the favour of 'bilateral development arrangements for economic cooperation in the context of liberalised trade so the EU provided access to some products from South Asian countries without any duties. The main regional objective of this development policy to alleviate poverty because South Asia is the home to poor people.

Jain (2015) critically argued in his book on "The European Union and South Asia" saying that "Despite a long historical experience of cultural, economic, political and social interaction with Europe, South Asia has never been a region of frontline policy for the European Union. It has gradually emerged as the largest trading partner of most South Asian economies, a major contributor of developmental aid, and home to a large diaspora, mostly in the United Kingdom" (Jain, 2015, p. xv). The EU's engagement 
in the region has grown post $9 / 11$ and it is engaged in the democracy promotion process in Bhutan, Bangladesh, Nepal, Pakistan, and Afghanistan. Recently, the EU's engagement in the region has significantly grown in areas of trade, commerce, and development aid. India was the first country amongst South Asian countries, which established a diplomatic relationship with six-member states of EEC in 1962. Later, India and present-day Bangladesh were beneficiaries of the Food Aid Convention in 1967. In 1976, South Asia had first benefited from ECC's financial and technical programs for non-associated developing countries in the context of food aid and rural development. The EU and South Asia had signed five cooperation and partnership agreements from 1994 to 2004. These programmes were concerned with the development of two-way trade, economics, and promotion of investment, financial and technical aid, development aid, human rights, and democracy establishment (Jain, 2015, p. 40).

Bodenstein, Faust, and Furness (2017) argued in their paper that the European Union is paying a more effective effort towards its development policy in a rapidly changing world. The Agenda for Change provided a clearcut global vision to deal with global developmental challenges so the EU required collective action. However, the EU has several global challenges to address e.g., economic and social exclusion, state fragility, and environmental concern. At the same time, the EU has experienced also internal crises such as the post-2008 recession debt crisis, migration issues, alarming neighbourhood crisis, and lastly BREXIT, so the collective effort is missing when most needed.

Doidge (2017) has argued that the EU development policy is old as its integration but development has never been a priority in EU-Asia relations. "The relative absence of development in the early decades of EU-Asia relations was a product of a disconnection between this baseline and the conceptual framework within which EU development policy was couched. The influence of dependency and demands for the establishment of a New International Economic Order defined the Union's view of development and the developing world, a view most prominently given expression in the Lomé Convention covering the ACP states... The rise of development in EUAsia relations has therefore not primarily been about the Union rectifying an absence in its relations with the developing world, but rather about its conception of development - shaped and defined by external debates becoming aligned with its interests in Asia." (Doidge, 2017)

Mayr (2020) stressed in SADF brief paper that, the EU is a top trading partner with countries of South Asia where it has so far engaged mainly on 
the grounds of commercial activities. Today, South Asia is one of the potential and important regions in the eyes of the world as they have the world's $25 \%$ population, and the volume of GDP is $\$ 3,453$ trillion with almost an average of $5 \%$ growth. The EU is also a major aid donor to South Asia but sadly, a simple google search "EU" and "South Asia" is giving few results and the search shows more frequent results on EU and South-East Asia. Therefore, major piece of literature is missing related to the EU's partnership with South Asia where the EU has grown its engagement in both trade and development policies. Despite this engagement, the EU is still not a major player and, China and the US have potential engagement and presence, and "it remains relatively neglected by the EU" (Mayr, 2020 p. 43). However, "the European prosperity links to Asia security" in contrast to the EU's global strategy so it should strengthen the trade and development partnerships with South Asia in the context of both levels: economic and political. The EU needs to change an old development and technical assistance-based model of development policy in the light of "changing political reality" in the region.

\section{SOUTH ASIA IN THE EU'S DEVELOPMENT POLICY}

The relation between the European Union and South Asia is very old as well as it is strengthened from time to time. However, we can see the first attention of the EU towards South Asia in the development policy from 1990s after signing the Lomé IV Convention with ACP countries. Before this treaty, the EU focussed on the ACP countries, and this area was almost neglected over the decade. The European Economic Community (Treaty of Rome, 1957) considered South Asia under the influence the United Kingdom (UK) and through the Commonwealth ties with by the six EEC original members e.g., France, Italy, Germany, Luxemburg, Belgium, and Netherlands. They also considered this area geographically inaccessible for them. After the Maastricht Treaty (1992), the EU modified the foreign policy and introduced the Common the Foreign and Security Policy (CFSP). It was a very important time and EU introduced the Development Policy as well as started engaging in other regions of the world by helping through diplomatic, economic, development and security policies. It was the first clear step of the EU towards South Asia and Horizon 2000 was launched to show the EU presence in international relations focused on issues of good governance, democracy, human rights, and the rule of law (Tripathi, 2011, p. 199). The EU launched the "Towards New Asia Strategy" in 1994 that was 
focused around open access and trade. They revised Asia Strategy in 2001, which concerned the Kashmir conflict, religious fundamentalism, terrorism, and democracy establishment.

The EU brought the first non-ACP development cooperation programs for the period of 1996-2006, which fell under the "Asia-Latin America" (called also the ALA regulation). It was covered by economic cooperation and financial and technical assistance. This EU regulation included poverty reduction as the main agenda, which was not a much-focused part of development policy till then. However, South Asia was not on the priority list and this programme was more dedicated to the Association of Southeast Asian Nations (ASEAN) (Birocchi, 1999). "The first Regional Programming Document for Asia was prepared in 2004, covering the period 2005-2006. It included three All-Asia programmes (on trade and investment, higher education, and environment), two sub-regional programmes (SAARC and ASEAN), and a small budget for the reserve" (EEAS, 2004, p. 3).

The EU launched another cooperation partnership under the "Regional Strategy" programme for Asia, as was the name for the Development Cooperation Instrument (DCI). It was adopted in December 2006 for the period between 2007 and 2013 as the Multiannual Indicative Programme (MIP). It was the occasion when all countries of South Asia were included in the EU's development policy. Hence, it was the time when the EU was targeted to increase effectiveness of the development cooperation. It focused on the three sub-regions of Asia - South Asia, Southeast Asia, and Northeast Asia. The Cooperation covered regional integration (in economic and non-economic fields) and policy dialogues; environment, energy and climate change; higher education; and aid to homeless people. The EU's priority area was the support the regional integration in order to focus on the all-Asian regional economic community and the SAARC. They were the "key dialogue partners" for the EU (EEAS, 2014, p. 4).

The European parliament played an important role in the effectiveness of democracy promotion and election observation for fair and transparent elections in South Asia. The EU delegation for the relation with countries of South Asia by the standing body of the European Parliament covers inter-parliamentary relations with Bangladesh, Bhutan, the Maldives, Nepal, Pakistan, and Sri Lanka. It has been chairing it since 2006 with focus on different legal grounds, reflecting the diverse patterns of intensity in commercial exchanges, investment flows, development cooperation, technical assistance, and cultural links. This relation has improved from 1981 on a regular basis and completed 45 inter-parliament meetings 
(European Parliament, 2018). The EP wants to improve democracy, human rights, and climate change in the South Asian countries.

Currently, the EU is the biggest aid donor in the world. Despite that, South Asia region was still neglected as well as given lower priority, especially in the economic term. It was significantly focused on the term of economic assistance and more focused on ACP countries (Tripathi, 2011, p. 195). Considering the EU's pro-active engagement in ACP countries, South Asia was expecting the similar level of attention and partnership in the region; however, it did not happen. The EU has a keen interest in implementing the Agenda-2030 for achieving the goals of sustainable development. Therefore, the EU has finally launched the Regional Programming for Asia, Multiannual Indicative Programme (MIP) 2014-2020, and Development cooperation under the Asia Regional MIP financed by the DCI, which covers all the eight South Asian countries. "The MIP is working in the light of European Consensus on Development (ECD), the Agenda for Change and the DCI Regulation, the EU development assistance in Asia aims at eradicating poverty by supporting broad-based inclusive and sustainable growth, promoting conditions conducive to trade and integration in the region, enhancing governance, and increasing political and social stability" (EEAS, 2014, p. 2).

\section{STRENGTHENING THE PARTNERSHIP UNDER REGIONAL PROGRAMMING FOR ASIA}

Currently, the EU and South Asia partnership is shaping a significant presence and strengthening ties under the "Regional Programming for Asia Multiannual Indicative Programme (MIP) 2014-2020" and special partnership in "Aviation Partnership Project (APP)". Both programmes are multi-purpose and covering a wide range of areas of engagement and the regional approach. The EU clearly stated that contemporary programmes function at the national level. The EU has emphasized developing a political dialogue for enhancing their bilateral trade and investment relations, thus the EU is strengthening its cooperation in the World Trade Organisation (WTO) (European Commission, 2014). It ensures that its development aid programme in Asia will be able to achieve its full potential and new programme under MIP can make a broader presence in Asia regarding mutual awareness.

This programme is meant for a regional economic player of Asia under development cooperation, which is the largest populous continent and fastest-growing region too, and it is geo-strategically very important. The EU 
wants to support the regional integration of SAARC in the field of institutionbuilding, democracy stability, development, good governance, sustainable development, and human rights. The Instrument for Development (DCI) finances these programmes. EU as the Observer wants to play a major role in the security and conflict mitigation in Kashmir and Afghanistan, which is also a major hurdle in the proper and fruitful function of SAARC. A total budget of 990 million euros has been allocated for the regional programme in Asia under the MIP. On the other side, "the EU is the SAARC's top trading partner, to a total of EUR 112 billion (2016 figures); it accounts for around $15 \%$ of the SAARC's overall trade with the world and $22 \%$ of its export market (2015 figures). Development cooperation between the EU and the countries of South Asia covers financial and technical aid as well as economic cooperation. Priorities include regional stability, poverty alleviation, human rights, sustainable development, good governance, and labour rights. EUSAARC cooperation seeks to promote the harmonization of standards and the facilitation of trade and to raise the awareness of the benefits of regional cooperation" (Soutullo, et al, 2017).

The EU's "Aid to Uprooted People (AUP)" supports the uprooted people and the countries that never benefitted from DCI, which targets the large group of uprooted people from ASEAN and countries included to SAARC are Afghanistan, Bangladesh, Nepal, Pakistan, and Sri Lanka. The area of intervention is aimed to focus on relief, rehabilitation, and development. Under this programme, the EU has allocated 122 million euros, which is 14 $\%$ of the MIP.

Table 1: Indicative Budget Allocations for the Asia Regional Multiannual Indicative Programme for 2014-2020

\begin{tabular}{|c|c|c|}
\hline Priority Sector & $\begin{array}{c}\text { Indicative amounts } \\
\text { in million (Euro) }\end{array}$ & Allocation in \% \\
\hline Regional Integration & 320 & $36 \%$ \\
\hline Aid to Uprooted People & 122 & $14 \%$ \\
\hline $\begin{array}{c}\text { Promotion of a Green } \\
\text { Economy }\end{array}$ & 440.5 & $49 \%$ \\
\hline Programme Support Measures & 7 & $1 \%$ \\
\hline Total for Regional Asia MIP & 889.5 & $100 \%$ \\
\hline p.m. ERASMUS & 370.5 & \\
\hline
\end{tabular}

Source: EEAS, 2014, p. 8. 
The EU and South Asia have tied for strengthening partnerships in civil aviation (CA) for next 20 years. The project has officially been launched on 24 March 2017 on the occasion of the Global Aviation Safety forum on Regional Safety Oversight Organization in Eswatini, which is governed by the European Aviation Safety Agency (EASA, 2017). This four-year project (2016-20) is managed by EASA that is enhancing aviation safety, institutional promotion, and industrial links as well as mitigating and improving the environmental protection and climate change action in aviation. The project is funded by the EU, which covers the cost of 7.5 million euros for the next four years. The project's target is to cover promotion of technical cooperation at the regional level in all eight South Asian countries and the main agenda is enhanced by the EU-South Asia dialogue. On the launch, the Executive Director of EASA, Mr. Patrick Ky stated "South Asia has the highest forecast traffic growth of any region in the world during the next 20 years. Europe looks forward to partnering with South Asia to meet the current opportunities and challenges." (EASA, 2017). Furthermore, South Asia's air traffic growth rate can be the highest growth for over the next 20 years in the world, which is expected to rise by at least $8.6 \%$

The EU's Council and Parliament established a financing instrument for the worldwide promotion of democracy and human rights under the European Initiative for Democracy and Human Rights (EIDHR) (2000-06) established in 2006, which was followed by the second phase in 2007-13 EIDHR, with a budget of $€ 1104$ million. EIDHR continues for the period 2014-20 with a budget of $€ 1332.75$ million (European Parliament, 2015, p. 2.). The EU is supporting South Asia under the EIDHR programme. The EU has laid emphasis even on strengthening the development partnerships beyond the aid programme, which focuses on the sustainable democracy in South Asia. The rule of law and good governance are becoming the strength of the democracy and the EU-South Asia Partnership for Democracy in Development. For example, they agreed to deal with strengthening the civil society, fundamental freedom, challenges of climate change, sustainable development, security, governance, and human rights protection. Day by day the weather is drastically changing in the subcontinent, that is affecting the inhabitants by natural disaster e.g. earthquake (recently, Nepal was affected hugely) and the moving of landslide in the mountain region mostly in India and Nepal. Additionally, human activities made disaster in the region is quite common.

In their research paper, Bhargava and Reed emphasized that "Good prospects exist for agreeing on a new EU-South Asia Partnership to achieve 
sustainable global action for Democracy in Development on a bilateral and a regional basis based on dialogue with policymakers in South Asia and the SAARC Secretary-General" (Bhargava, Reed, 2009, p. 3.). The neoliberal approach of the EU emphasises regional integration with South Asia in order to achieve its FTA goal. The SAARC would be a single platform if it functions properly so the EU can negotiate with all eight countries of South Asia together for FTAs and better access to the markets. In the past decade, Nepal and Bhutan moved towards the path of democracy and it was also the role of EU's democracy promotion programme as per development policy for South Asia. In past years, the EU has observed elections in South Asia such as Afghanistan, Bangladesh, Nepal, Sri Lanka, and Pakistan.

\section{SOUTH ASIA AND ITS IMPORTANCE FOR THE EU}

The EU is following the World Bank definition of South Asia, which is a geographical region including eight countries e.g., Afghanistan, Bangladesh, Bhutan, India, Maldives, Nepal, Pakistan, and Sri Lanka. The World Bank's report says that South Asia is readily a growing economy with average growth of 7.7\% annually expected. (The World Bank, 2020) India is the largest growing economy in that region and the $5^{\text {th }}$ largest economy in the world (Myers, 2020). The area is also the most populated with cheap labour market, which attracts foreign investment in the region. South Asia accounts for more than half of the growth in the world economy, one billion of the population increases the purchasing power, and at least 400 million have the spending capacity equal to any American as well as European. The World Bank's assessment of the growing market potential of South Asia is seeking the attention of the EU's countries (Vivekanandan, Giri, 2001, p. xi).

South Asia is the largest consumer market due to its size of population. In the early 1990s, most countries of South Asia moved from a mixed economy to a neoliberal economy where they adopted neoliberal elements such as privatisation, liberalisation, and globalisation. That has opened the market for international trade with the minimisation of trade barriers. Recently, India has become the fifth largest economy and it has surpassed its coloniser, Britain. The World Bank data show South Asia as the fastest-growing region in the world the last decade then it has sought the attention of the world market, which is very important for the EU and for great opportunities of its member states. After a long ignorance, the EU is interested in FTAs and strategic presence in South Asia. 
After the Eurozone crisis, the EU started its cooperation agreement with countries of South Asia and it is on the path of regular dialogue and engagement. The EU is in favour of the fight against terrorism and extremism in South Asia as considered a home of terrorism. The presence of the Islamic State (IS) is making the region more hostile; especially Pakistan and Afghanistan are badly impacted by them. The EU is the biggest development and humanitarian aid provider to Afghanistan. The drawdown of international force in 2014 made them a step towards a fragile state as the Taliban rose again an influential actor there. The current 2020 fragile- state ranking placed Afghanistan as $9^{\text {th }}$ in the world with 102.9 scores in Fragile States Index (Fund for Peace, 2020). Some of the EU cities also experienced terrorist attacks and 9/11 changed security dimension. Therefore, there is a concern in South Asia. The EU wants stability in South Asia especially in Afghanistan in order to send back asylum seekers from the EU member states, who have rejected them. The regional stability and peace of South Asia are not only important for the EU but also for the world. However, South Asia is very important due to security and strategic reasons. There is another reason as boarder security and sovereignty, which is very important for countries of South Asia that would be a great opportunity for the EU Member States, with India as a strategic partner here.

May-Britt U. Stumbaum in her paper "How Europe Matters in Asian Security" addressed non-traditional security threats, especially under the climate change atmosphere. The EU neoliberal capabilities can influence the norms of EU-Asia security relations where the EU's expertise and technology can help to avoid threats related to non-traditional security. The EU has a concern about the threats such as water, energy (in)security, food, and trans-border conflict affecting resources and economic development (Stumbaum, 2014, pp. 3). However, it is not the only concern for security because that is also affecting FTAs' negotiation and there is an urgent need for peace and stability. South Asia's stability can also provide the EU with easy access to Asia-Pacific where India and Pakistan are rising economies. EU uses maritime routes for trade in $90 \%$ cases which have no any conflict zones that can hamper their flow of shipping. Nevertheless, recently, the EU is interested in being involved in conflict management and resolution in South Asia that may finally support EU's interest to sign FTA and Strategic Partnership with other countries in the region.

However, South Asia is very important from both traditional security and non-traditional security challenges, which can provide access to the market in Asia-pacific. The main EU expertise is with Trade and the 
security stability achieved through NATO. Thus, for the mutual benefits the EU can use its expertise to resolve the ongoing conflicts in South Asia that ultimately might create the peaceful environment for EU to trade with the South Asian states. Therefore, the EU is looking for FTAs and strategic partnerships with South Asia as a whole. At the same time, there are two nuclear powers in the Asia-Pacific, such as India and Pakistan. As per nontraditional security, challenges that South Asia is facing include climate changes and global warming with the Maldives experiencing an underwater threat from the ocean and struggling to save the islands. According to World Bank's South Asian Regional Vice President, Hartwig Schafer, it is affecting low-lying islands and there can be a matter of survival. Despite it, the islands are experiencing serious challenges in intense rainfall, resultant flooding, cyclonic winds, and storm surges. "The Maldives is one of the lowest-lying countries in the world" (Schafer, 2019). The Maldives is one of the beautiful countries and tourist destination with most of the tourists coming from the EU. In the Maldives, the EU has provided the Climate Change Trust Fund with approx. 6.5 million euros as the multi-donor to build resilience to tackle climate change. The European Commission provided 10.5 million euros for climate change adaptation in 2019 and until now, the Maldives got approx. 50 million euros for it (European Commission, 2020).

The EU's strategic framework for South Asia was combined under the EU's External Action towards Asia (four key sub-regions included South Asia, Southeast Asia, Northeast Asia, and Australasia). It is based on the Commission's 2001 Communication under the "Europe and Asia: A Strategic Framework for Enhanced partnership" (European Commission, 2001a, p. 1). All core objectives of the EU stated "Why South Asia is important for them, after the above-mentioned concerning the value of the region. The strategy paper is focusing on the core objective of "Strengthening the EU's political and economic presence across the region and it is raising this to a level commensurate with the growing global weight of an enlarged EU" (European Commission, 2001a, p. 3). It emphasises the EU's concern in South Asia regarding peace and security that is a major problem in Kashmir disputes and terrorism issues prevailing in the Pakistan and Afghanistan region.

Furthermore, the EU wants to strengthen its mutual trade and investment, because the South Asian region also needs development. It wants to address the root cause of underdevelopment, the poverty and scarcity of resources. Protection of human rights, promotion of democracy, the rule of law, and good governance are the major concerns of the EU in South Asia. The EU has 
a clear vision to build global partnerships and alliances with Asian countries to address the challenges and opportunities in the contemporary era of globalisation. The EU has a priority to strengthen the partnerships between Europe and Asia (European Commission, 2001b).

\section{PROSPECTS AND CHALLENGES OF EU-SOUTH ASIA PARTNERSHIP}

The EU is reeling under the pressure of the multilateral challenges such as BREXIT, COVID-19 and China's initiative of One Belt, One Road as well as the threat from President Trump (Cameron, 2017). Considering the emerging economics of South Asia, the region can provide a lifeline to EU in term of maintaining the trade flow and expanding it economic partnership. Furthermore, the partnership between the EU and South Asia is very important, where India is a trade and strategic partner in the region The EU is now concerned about economic stability and peace-building across the world and it wants to play a geostrategic role. The partnership puts an emphasis for deepening relationship through which it can help to secure global prosperity, global security (terrorism), human rights, and the stability of democracy, the rule of law, political stability, open market, and the environmentally stable world with their partner (Soutullo, 2019). Until 2019, trade between the EU and South Asia consisted 40\% of the total EU trade. And the EU's engagement in conflict resolution has potential to increase the trade volume in the coming future.

The EU faced an economic crisis from the recession of 2008; the Eurozone debt crisis has experienced the stalled growth and cuts in aid among other repercussions. In 2011, European governments reduced the demand for developing country exports and led to cuts in aid spending with introduced austerity packages (Massa, 2011). However, the EU is still facing an economic crisis and migration issues after the Syrian crisis and COVID-19. Therefore, they face a huge problem and these crises might lead to cuts in aid as well as might affect the partnership. Bertil Odén and Lennart Wohlgemuth have mentioned in their reflections (essays) that "The economic crisis in many European countries and the lack of joint European policies to tackle developments in growing economic countries weakens the European position" (Odén, Wohlgemuth, 2015, p. 1). The global economy has changed and political power-balance is shaping the role of development cooperation. The South-South cooperation is taking an initiative for development under the BRICS bank and the rising economy in Asia particularly India and China have taken an initiative of development assistance. Despite South- 
South development assistance, the United States of America (USA) are also strongly present in South Asia. China has already launched a big One Belt, One Road (OBOR) Initiative of a globally new economic policy, which is targeting the South Asian countries that is a very important region in the context of geopolitics, with Pakistan as the most influential partner in this Initiative. Contemporarily, EU is facing its own internal challenges as discussed above. Moreover, emerging South-South cooperation is also poising more challenges for EU in the region.

Before the recent MIP, the South has received less attention, and India, as a strategic partner never gets success for the Free Trade Agreement (FTA) negotiation. The EU and South Asia, are facing common challenges in the field of migration and terrorism. India is facing domestic problems (e.g., poverty, child abuse and labour, Naxalite problems, caste, and gender discrimination) and problems with neighbours (e.g., Kashmir disputes with Pakistan, migration problems with Bangladesh). As almost all, the external conflicts are concerned with India and India have failed to deliver the conflict resolution in bilateral manner. After the EU -India Strategic Partnership was concluded, the EU can extend its expertise to India on resolving the ongoing inter/intra state conflicts in the region. Peace and stability are the only way for the South Asian Free Trade Agreement (SAFTA) and it is the core area of interest for the EU where the EU is continuously making a dialogue for a successful FTAs roadmap. The Asia-Europe Meeting (ASEM) has become a forum for institutional- level discussion, and the countries of South Asia are also included.

Afghanistan has become a task for the world powers in the context of setting a diplomatic strategy. India is already supporting the state-building process here through its development assistance and on the other hands, China is helping Afghanistan, which is very important for the OBOR project. Thus, the EU has spent millions of Euros on the state-building process and counter-terrorism, but at the same time, they have challenges from the rising of South-South relationships. It is not the only question of Afghanistan but this is also due to the engagement of another region. In the last few decades, China has grown to the world economic giant so there is a strategic hassle with the US in South Asia with strong presence here. However, there are also other important actors in the region such as India and Japan so geopolitics of South Asia is not an easy for the EU to clutch. Hence, the EU has "failed until now to formulate an Indo-Pacific strategy" (Mohan, Vater, 2019 , p. 5). In reality, current EU's approach to South Asia have failed to create an opportunity for both parties. The ultimate goal of the EU to sign 
an FTA and Strategic Partnership with each state has not been achieved, yet -except India.

\section{CONCLUSION}

The first research goal was to find the exact development policy of EU regarding South Asia through researching the available sources and literature. This section provided the sufficient understanding that EU have institutional engagement in the region through its 'Regional Strategic Paper-2007'. Thus, the EU is rapidly coming closer to South Asia and is currently engaged in transforming partnerships towards a market economy. There is the role for the EU in flourishing the atmosphere of democracy and market economy through development cooperation. Undoubtedly, there are challenges for stable and peaceful presence in South Asia. There are many powerful economies of the world involved in the largest consumer market globally. South Asia economies are emerging helped with the EU as the largest aid donor in this region.

The EU's development policy pays special attention in addressing the challenges in South Asia. Empirical evidence show that the development of South Asia is important for further trade negotiations towards free trade agreements. The European Union development policy is bringing differences in South Asia and MDGs quite successfully where the education sector started doing better than before. It is helping to establish democracy and rule of law in the region where human rights and poverty are of major concern. As a result, democracy flourished in Bhutan and Nepal. Yet the EU still need to have a rigorous engagement in the region to compete with a key players like India, China, and the US.

Recently, the EU was highly affected by the COVID-19 pandemic that hit especially big economies of Western European states such as Italy, Spain, and France. Additionally, the EU is also undergoing Britain's exit (BREXIT) from the EU. Despite this, the EU is still providing 36 million euros to help the partner countries. The EU is keeping its support in the time of global COVID-19 crisis with responding to the immediate health crisis, humanitarian needs and is supporting mitigation of the immediate social and economic consequences. In the time of global pandemic as well, EU has mobilized approximately 438 million euros dedicated to South Asia (up until July 2020). It keeps supporting South Asia even in times of global pandemic crisis that makes the EU's commitment for the region more lucrative. 
The survey of literature showed that experts not only criticise that earlier the EU did not pay much attention to South Asia, but they also criticise the act of literature concerned. However, the EU has been strengthening its development and trade partnership with South Asia in the last decade, the relevant research is still missing. The EU's old economic and technical assistance has not provided political and economic grips in South Asia however, it has set out objectives of the regional strategy as the regional presence and strategic partnership. Moreover, the EU's strategic partnership is still limited to India only. The EU's development policy needs a reality check in South Asia and there is a need for the engagement of civil society and NGOs. Its development policy also needs to address the violence against women in South Asia, which is a major part of human rights agenda and cover most of the newspaper headlines (Bharti, 2017, p. 1). Therefore, there is also a need to highlight women empowerment where microfinance strategy can help rural South Asia to strengthen social development. Although, China, India, and the US are more popular in the region so the EU needs to transform its old way of engagement with changing social and political scenarios in South Asia. Due to COVID-19, South Asia is largely affected and facing economic lockdown so the post-Corona pandemic must be a challenge for the developing countries (Bharti, 2020, p. 76). However, the EU can focus on the post-COVID-19 reconstruction of South Asia with more investment opportunities that can ultimately serve the EU's goal in the region, i.e., to became a leading stakeholder.

\section{REFERENCE}

BHARGAVA, K. K., REED, M. A. (2009). The European Union, South Asia and Democracy in Development: Dialogue and Partnership. Stockholm: International IDEA, 2009. [online]. Available at: https://www.idea.int/ sites/default/files/publications/chapters/the-role-of-the-europeanunion-in-democracy-building/eu-democracy-building-discussionpaper-64.pdf. [Accessed December 30, 2020].

BHARTI, S. S. (2017). Violence against Women in India: An Intersectional Approach to Human Rights. [online]. Available at: http://gcids2017.org/ wp-content/uploads/2017/09/Simant-Shankar-Bharti-Full-Paper.pdf. [Accessed December 30, 2020].

BHARTI, S. S. (2020). Development Economics and Re-construction of Developing Countries: Reflections and Insights. In: Journal of Scientific Papers "Social development and Security", Vol. No. 4, 2020, pp. 69-77. 
DOI: $10.33445 /$ sds.2020.10.4.6.

BIROCCHI, F. (1999). The European Union's Development Policies towards Asian and Latin American Countries. DSA European Development Policy Study. Group Discussion Paper No. 10. [online]. Available at: https://eulacfoundation.org/en/system/files/THE\%20EU'S\%20 DEVELOPMENT\%20POLICIES\%20TOWARDS\%20ASIAN\%20AND\%20 LA\%20COUNTRIES.pdf. [Accessed May 7, 2018].

BODENSTEIN, T., FAUST, J., FURNESS, M. (2017). European Union Development Policy: Collective Action in Times of Global Transformation and Domestic Crisis. In: Development Policy Review, Vol. 35, No. 4, 2017, pp. 441-453. DOI:10.1111/dpr.12189.

CAMERON, F. (2017). "It's Asia, Stupid": Time for the EU to Deepen Relations with Asia., Hamburg: GIGA German Institute of Global and Area Studies Leibniz-InstitutfürGlobaleundRegionaleStudien,Institutfür Asien-Studie, 2017EU-Asia Centre. [online]. Available at: https://pdfs.semanticscholar. org/ba8b/a79fa64e17bb2fa2d67a7e89434bebd8a104.pdf. [Accessed April 25, 2018].

DOIDGE, M. (2017). The Changing Place of Development in EU-Asia Relations. In: The European Journal of Development Research, Vol. 29, No. 4, 2017, pp. 926-941. DOI: 10.1057/s41287-016-0070-3.

EASA. (2017). European Union and South Asia Strengthen Ties Civil Aviation. [online]. Available at: https://www.easa.europa.eu/newsroom-andevents/press-releases/european-union-and-south-asia-strengthen-tiescivil-aviation. [Accessed December 30, 2020].

EEAS. (2004) Strategy Paper and Indicative Programme for Multicountry Programmes in Asia, 2005-2006. [online]. Available at: http://www.europafacile.net/Scheda/Download?p=201401061928. Strategia2005_2006.pdf\%20\&t=D\&o $=6408 \& a=8887 \& r=22928$. [Accessed December 30, 2020].

EEAS. (2014). Regional Programming for Asia, Multiannual Indicative Programme 2014-2020. [online]. Available at: https://eeas.europa.eu/ sites/eeas/files/regional-asia-mip-2014-2020_en.pdf. [Accessed 24 April 2018].

EUROPEAN COMMISSION (2001a). Europe and Asia: A Strategic Framework for Enhanced Partnerships. [online]. Available at: http://eurlex.europa. eu/LexUriServ/LexUriServ.do?uri=CELEX:52001DC0469:EN:HTML [Accessed December 30, 2020].

EUROPEAN COMMISSION. (2001b). Communication from the Commission "Europe and Asia: A strategic Framework for Enhanced Partnerships" 
[online]. Available at: https://op.europa.eu/en/publication-detail/-/ publication/77f3c2a2-bd32-45e9-9440-da0a63d0cbbd.

EUROPEAN COMMISSION. (2014). Report on Evaluation of the European Union's regional cCo-operation with Asia. [online]. Available at: https:// www.oecd.org/derec/ec/Evaluation_of_the_European_Union_regional_ co-operation_with_Asia_Vol1.pdf [Accessed December 30, 2020].

EUROPEAN COMMISSION. (2020). The Maldives. [online]. Available at: https://ec.europa.eu/international-partnerships/where-we-work/ maldives_en [Accessed December 30, 2020].

EUROPEAN PARLIAMENT (2015), European Instrument for Democracy and Human Rights,. Available at: https://www.europarl.europa.eu/RegData/ etudes/BRIE/2015/568332/EPRS_BRI(2015)568332_EN.pdf [Accessed December 30, 2020].

EUROPEAN PARLIAMENT. (2018) Delegations European ParliamentIntroduction., [online]. Available at: https://www.europarl. europa.eu/delegations/en/dsas/about/introduction. [Accessed 25 April 2018].

FUND FOR PEACE. (2020). Indicators. [online]. Available at: https:// fragilestatesindex.org/indicators/ [Accessed July 30, 2020].

HERMANN, CH. (2007). Neoliberalism in the European Union. In: Studies in Political Economy, Vol. 79, No. 1, 2007, pp. 61-90. DOI: 10.1080/19187033.2007.11675092.

JAIN, R. K. (2015). The European Union and South Asia. New Delhi: KW Publishers Pvt Ltd., 2015.

MASSA, I. (2011). How the Eurozone debt crisis could affect developing countries. In: The Guardian. [online]. Available at: https://www. theguardian.com/global-development/poverty-matters/2011/oct/21/ eurozone-crisis-developing-countries [Accessed April 25, 2018].

MAYR, S. (2020). EU-South Asia trade perspectives: State of play. In: SADF - Policy Brief, No. 9, 2020. [online]. Available at: https://www.sadf. eu/policy-brief-9-eu-south-asia-trade-perspectives-state-of-play/ [Accessed December 30, 2020].

MOHAN, C. R., VATER, J. J. (2019). Introduction. In: South Asia Discussion Papers. Europe in The Indo-Pacific: Moving from Periphery to the Centre? Singapore: Institute of South Asian Studies, 2019.

MYERS, J. (2020). India is now the world's 5th largest economy. [online]. Available at: https://www.weforum.org/agenda/2020/02/india-gdpeconomy-growth-uk-france/ [Accessed December 30, 2020]. 
ODÉN, B., WOHLGEMUTH, L. (2015). European aid and development policies in a changing world. The European Centre for Development Policy Management, No. 76, 2015. [online]. Available at: http://ecdpm.org/wpcontent/uploads/BN76-European-Aid-Development-Policies-ChangingWorld-ECDPM-June-2015.pdf. [Accessed April 25, 2018].

PASHAKHANLOU, A. H. (2017). Fully integrated content analysis in International Relations. In: International Relations, Vol. 31, No. 4, 2017, pp. 447-465. DOI: 10.1177/0047117817723060.

SCHAFER, H. (2019) Bracing for climate change is a matter of survival for the Maldives. [online]. Available at: https://blogs.worldbank.org/ endpovertyin southasia/bracing-climate-change-matter-survivalmaldives. [Accessed December 30, 2020].

SOUTUlLO, J. (2019). Fact Sheet on the European Union: South Asia. [online]. Available at: https://www.europarl.europa.eu/factsheets/en/ sheet/181/south-asia. [Accessed December 30, 2020].

SOUTULLO, J. et al. (2017). Fact Sheets on the European Union: South Asia. [online]. Available at: https://www.europarl.europa.eu/RegData/ etudes/fiches_techniques/2013/060606/04A_FT(2013)060606_ EN.html. [ Accessed December 30, 2020].

STUMBAUM, M. B. U.(2014). How Europe Matters in Asian Security:Addressing non-traditional security threats under climate change conditions; towards a new research agenda on norm diffusion in EU-Asia security relations. Berlin: NFG Research Group „Asian Perceptions of the EU and Freie Universität Berlin, 2014.

THE WORLD BANK (2020), South Asia. [online]. Available at: https://www. worldbank.org/en/region/sar/overview [Accessed December 30, 2020]. TRIPATHI, D. (2011). Development role of the European Union in South Asia. New Delhi: Vij Books India, 2011.

VIVEKANANDAN, B., GIRI, D. K. (2001). Contemporary Europe and South Asia. New Delhi: Concept Publishing, 2001. 